\title{
International Education Programs and Political Influence
}


This page intentionally left blank 


\section{International Education Programs and Political Influence}

Manufacturing Sympathy?

Iain Wilson 
INTERNATIONAL EDUCATION PROGRAMS AND POLITICAL INFLUENCE

Copyright (@) Iain Wilson, 2014.

Softcover reprint of the hardcover 1st edition 2014 978-1-137-36628-3

All rights reserved.

First published in 2014 by PALGRAVE MACMILLAN ${ }^{\circledR}$ in the United States-a division of St. Martin's Press LLC, 175 Fifth Avenue, New York, NY 10010.

Where this book is distributed in the UK, Europe, and the rest of the world, this is by Palgrave Macmillan, a division of Macmillan Publishers Limited, registered in England, company number 785998, of Houndmills, Basingstoke, Hampshire RG21 6XS.

Palgrave Macmillan is the global academic imprint of the above companies and has companies and representatives throughout the world.

Palgrave $^{\star}$ and Macmillan ${ }^{\star}$ are registered trademarks in the United States, the United Kingdom, Europe and other countries.

ISBN 978-1-349-47413-4

ISBN 978-1-137-34967-5 (eBook)

DOI $10.1057 / 9781137349675$

Library of Congress Cataloging-in-Publication Data

Wilson, Iain (Research fellow)

International education programs and political influence: manufacturing sympathy? / Iain Wilson.

pages $\mathrm{cm}$

Includes bibliographical references.

1. Student exchange programs-Political aspects. 2. Student exchange programs-Finance-Government policy. 3. College student mobilityPolitical aspects. 4.-ERASMUS (Organization) I. Title.

LB2375.W55 2014

$370.1162-\mathrm{dc} 23$

A catalogue record of the book is available from the British Library.

Design by Amnet.

First edition: April 2014

$\begin{array}{llllllllll}10 & 9 & 8 & 7 & 6 & 5 & 4 & 3 & 2 & 1\end{array}$ 


\section{Contents}

List of Tables vii

List of Figures $\quad$ ix

Acknowledgments $\quad$ xi

Introduction 1

1 Political Expectations 9

2 Can We Infer That Mobility Has Political Impact?

3 How Strong Is the Evidence of Political Impact? 47

4 How Can We Detect Short-Term Impact (and What Does That Mean)? 59

5 Short-Term Impacts of Erasmus Mobility 87

6 Varieties of Experience 139

7 Individual Perspectives 151

8 Impact over Decades $\quad 175$

Conclusion 193

Appendices 203

Notes 205

References 215

$\begin{array}{ll}\text { Index } & 227\end{array}$ 
This page intentionally left blank 


\section{List of Tables}

4.1 Overall attrition, Erasmus panel

5.1 Attrition diagnostics on cognitive mobilization

5.2 Attrition diagnostics on Moreno question

5.3 Attrition diagnostics on World Values

5.4 Attrition diagnostics on party politics

5.5 Erasmus/Non-Erasmus status and change in voting intentions

5.6 Differential attrition on party placement

5.7 French students' support for right-wing parties 106

5.8 Attrition diagnostics on foreign affairs

5.9 Attrition diagnostics on demographics

5.10 Attrition diagnostics on policy transfer from host 117

5.11 Change in approval of copying host country policies 118

5.12 Change between yes/no responses, policy transfer from host

5.13 Changes from "don't know" to all other responses, policy transfer

5.14 Approval of transferring specific policies to home, after the Erasmus year, not significantly associated with Erasmus status

5.15 Changes on policy transfer, home to host

5.16 Yes/No movement on policy transfer from home

5.17 Know/Don't know movement on policy transfer from home 
5.18 Attrition diagnostics for host country attitudes 124

5.19 Differential attrition in attitude to host

5.20 Summary of changes

6.1 Logistic regression model, probability of making hostnational friends

6.2 Logistic Regression Standard Errors

7.1 Consent to interview and change in view of host country, no significant correlation 


\section{List of Figures}

5.1 Group means on the Moreno question do not diverge

5.2 Group means for tolerance converge 97

5.3 Views on redistribution did not diverge significantly 98

5.4 A chart summarizing the differential attrition in party placement 105

5.5 Divergence in left-right placement appears to be insignificant 107

5.6 Erasmus students' knowledge of the host language increased 113

5.7 Divergence in understanding of the host's foreign policy 126

5.8 Perceived understanding of host nationals diverged 127

5.9 Interest in learning more converged 129

5.10 Apparent lack of divergence in attitudes to the host 130

5.11 Differential attrition on attitude to the host country 132 
This page intentionally left blank 


\section{Acknowledgments}

One of the best parts of writing this book was discovering how many people were willing to help out for no benefit to them. In particular, I would like to thank my academic supervisors at various stages in the project's gestation: James Vaughan and Roger Scully at Aberystwyth, Elizabeth Bomberg at Edinburgh, and Brian Hogwood at Strathclyde. Rob Johns, David Sanders, and Mick Cox also offered some very helpful academic guidance.

The largest group of contributors-the hundreds of students who took the time to reply to the various surveys-is too often neglected, but they really did make this work possible. I should also offer thanks to the "gatekeepers" who helped me to reach the survey participants. Lottie Bulman at the German Academic Exchange Service, Chris Armstrong at Leeds University, Mary Denyer and Natasha Bevan at the Marshall Fund, Chad Galts at Brown University, and Patricia Rea at the University of Pennsylvania helped with the pilot. Dozens of universities' international officers and departmental secretaries in Reading and Leeds, as well as Anders Ahlstrand of the Swedish Programkontoret, helped to distribute the main survey. While most of the interviewees must remain anonymous, they know who they are. Sir Christopher Mallaby offered particularly helpful advice, and kindly allowed me to name him in the text.

The nature of this project made language skills greatly desirable, and unfortunately mine are a little limited. Ute Barrett at Glasgow, Wolfgang Mühlbauer (then a PhD student at the Technical University of Munich), and Ludwig Gelot converted my translations into something native speakers might recognize. I would also like to thank Emmanuel Sigalas and Paul Marion for passing on copies of their unpublished theses.

The team at Palgrave and the anonymous reviewers have helped to convert my turgid writing into something which I hope is at least a little more palatable. I am especially grateful to Sarah Nathan, Mara Berkoff, and Scarlet Neath.

This research could not have been completed without the financial support of the UK Economic and Social Research Council.

Finally, thanks to Gemma and my family for everything else.

All interpretations and of course all errors are my own. 